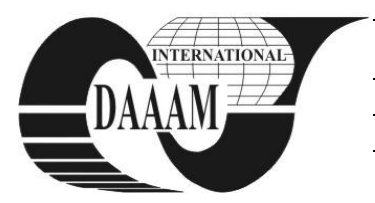

Annals of DAAAM for 2012 \& Proceedings of the 23rd International DAAAM Symposium, Volume 23, No.1, ISSN 2304-1382 ISBN 978-3-901509-91-9, CDROM version, Ed. B. Katalinic, Published by DAAAM International, Vienna, Austria, EU, 2012 Make Harmony between Technology and Nature, and Your Mind will Fly Free as a Bird Annals \& Proceedings of DAAAM International 2012

\title{
ECOLOGICAL SUSTAINABILITY OF THE SHEETFED OFFSET PRINTING
}

\author{
BOLANCA MIRKOVIC, I[vana]; MAJNARIC, I[gor] \& BOLANCA, S[tanislav]
}

\begin{abstract}
The basic directions of the ecological sustainability of the sheet fed offset printing are in the area of the application of the renewable and recycled raw materials for the production of the printing materials, in the decrease of the energy consumption, the usage of the energy from the renewable sources and in the production without waste; or if the waste was formed that it could be used in the same production or in another one. The analysis of the life cycle assessment offset printed matter has shown all the importance of the recycled paper usage in relation to the usage of the paper made from the virgin fibres and with it the possible influence on the quality of the environment. The main object of these investigations is the contribution to the explanation of the mechanism of the deinking flotation of prints made with the ink based on mineral oils and prints with greater share of the renewable raw material. Some prints were exposed to moist heat ageing before recycling. The brightness of handsheet, number and area of specks and chromatic coefficient in relation to the ink formulation and the conditions of the moist heat ageing of prints are discussed.
\end{abstract}

Keywords: sheetfed offset printing, renewable raw material, recycling, specks, CIE $a^{*}$ and $b^{*}$

\section{INTRODUCTION}

One of the most important challenges of the modern production is transforming the general aims of the sustainable development into the concrete meaning of the concept and the inclusion of the ecological demands in the process of the general management [1].

It is necessary to point out the interdisciplinary character of the postulates of sustainability which comprises the area of economy, ecology and society [2]. The economists are interested into the growth and influence of the micro-economy, (e. g capital cost, operating cost, profitability, investments) and macroeconomy(e.g. value added, taxes paid and other investments). Ecologists are occupied by the integrity of the ecological system (raw material, energy, emissions to air, water, land, environmental impacts e. g. global warming, ozone depletion, acidification, human toxicity, eco toxicity, summer smog, eutrophication). Sociologists are interested in justice and security for all the members (provision of employment, health and safety, public acceptability).

To provide the detailed information about the environmental aspects and potential environmental impact of the sheet fed offset printing, the life assessment methodology can be used [3-5]. Studies with product life cycle assessment on printed matter are relatively new and they include the investigation as follows.

LCA analyzes the environmental aspects and potential impacts across the product from cradle to grave including raw material acquisition, production, use, end of life treatment, recycling and final disposal [6].Life cycle assessment can help in identifying the opportunities to improve the environmental performance of products, selecting relevant indicators, help for the purpose of strategic planning and applying for an eco-label [711].The methodological development in LCA has been strong and some areas have been an intense methodical development. Developments concerning databases and input, output and hybrid LCA have to be mentioned [12].

The four phases of LCA are made according to the ISO 14040 standard [7]. They are: goal and scope definition, inventory analysis, impact assessment and interpretation.

The goal definition of an LCA includes: the reason for carrying out the LCA, the audience to which the results are intended to be communicated. The scope definition has to have the goal of the research.

In the scope definition of an LCA, the following items should be described: the product systems, the function of product, the functional units, the product system boundaries, allocation procedures, types of impact and methodology of impact assessment, data requirements, data quality requirements, assumptions, limitations and type of critical review[7]. The functional unit is the basis for comparison between all inputs and outputs.

In the system analysis in the area of graphic technology the functional unit of one tone of the produced material is more frequent than the number of impressions [3, 4, 13, 14].

Life cycle inventory LCI is the second phase of the LCA study. This phase gives information about the inputs from environment to the researched system and the outputs to the environment from the system. Concerning the LCA sheet fed offset printing for phases: the inner sheets cover and papers, chemicals, material, fuels in printing, direct emission from printing, energy and transport, the LCI data were investigated: greenhouse gas emission, $\mathrm{NO}_{\mathrm{x}}, \mathrm{SO}_{2}$, particulate matter, volatile organic compounds and emission into water [15-17].

In the life cycle impact assessment LCIA, the results of the inventory analysis are linked to specific environmental damage categories. The elements in LCIA 
phase are: selection of impact categories, category indicators and characterization models, assignment of LCI results - classification, relative to a chosen reference calculation of category indicator results characterization, calculating the magnitude of category indicator results relative to a chosen reference information dataset - normalization, sorting and ranking of the impact categories - grouping, converting and possibly aggregating indicator results across impact categories using numerical values based on value choices - weighting $[7,8]$.

The impact assessment methods which were used in the investigation in the area of printing were: Ecoindicator 95, CLM, Recipe, Impact 2002 + and EDIP 97. The limited number of LCA's on offset prints has been produced [18]. The results from Dalheilm and Axelsson, Axel Springer Verlag AG, Stora and Canfor point to paper as the dominanting contributer to the potential environmental impact from LCA of the offset printed matter $[3,4]$.Dominating role of paper is in the energy impact categories of global warming, acidification and nutrient enrichment. In Axel Springer Verlag AG, Stora, Canfor study includes the chemical related impact categories by using Ecoindicator 95 methodology and CML method, impact or midpoint approach [4].

The following impact categories were included in the assessment according to the ReCiPe method (offset printing, newspaper, magazine): climate change greenhouse gasses, acidification $-\mathrm{So}_{\mathrm{x}}$ and $\mathrm{NO}_{\mathrm{x}}$, eutrophication- nitrates and phosphates, photochemical oxidant formulation- hydrocarbons and $\mathrm{NO}_{\mathrm{x}}$, particulate matter formulation, mineral resource depletion, fossil fuel depletion [18, 19].The results show that when considering the time from cradle to grave, the solid waste amount of about $345 \mathrm{~kg}$ is produced per tonne of newspaper [18].

In the study of Larsen and coauthors the assessment criteria used are defined in the impact category made in the EDIP method, and include: global warming, ozone depletion, acidification, nutrient enrichment, photochemical ozone formulation, chronic human toxicity via air, acute eco-toxicity in water, hazardous waste, nuclear waste, slag and ashes and bulk waste [20].

The life cycle assessment found that the sheetfed offset printing process $(52 \%)$ was the largest contributor to the environmental impact of most printed materials, more than the impact of paper (31\%) and ink (17\%) together [20]. In term of the resource usage, paper is still dominant at $48 \%$ [20]. The environmental impact can be reduced with approximately $16 \%$ by using recycled paper instead of virgin paper. The scope of the Moberg at al. study was printed and the tablet e-paper newspaper from an environmental perspective [21]. Several different environmental impact categories were assessed; resource used (renewable, nonrenewable and total) acidification, climate change, eutrophication, photochemical oxidant formation, ozone depletion and toxicity [21].

Results show that the most significant phase of the life cycle for both product systems was the production of the paper and the tablet e-paper device respectively. In the same paper, ICT sector was started to give rise to 500 Mtonne $\mathrm{CO}_{2}$ emissions /year globally [21].
Specific focus in LCA study of the Vercalsteren at al. was on newspaper (coldest offset) and periodical (heat set offset)[22]. The functional unit was $1 \mathrm{~m}^{2}$ printed matter. Impact categories were included in the assessment according to the ReCiPe method and CML. The environmental profile was dominated by the production of the paper $(80 \%-99 \%)$ [22]; the contribution of the production of ink and printing was much lower and nearly insignificant. Comparison of the environmental impact of newspaper and periodical was different mainly due to the large impact of paper production (newspaper 100\% recycled, periodical 100\% virgin paper) and printing, coldset offset (newspaper) requires much less energy than the heat set offset (periodical)[22].It is known that in the recycling process of papers, deinkability of the furnish depends on the ink setting, printing processes, on the nature and amount of ink in prints and on the paper grade [23- 25]. The deinking effectiveness is influenced by the chemical characteristic of the vehicle and by drying mechanisms of the ink [26-28]. Ink, they set by penetration of the vehicle into the uncoated structure of paper, can be rubbed off from the surface of the fibers in a deinking process. Inks which contain more vegetable oil, binders or varnishes lead to faster ink drying and lower rub off [29].

From the presented critical overview of the literature in the area of life cycle assessment of the offset printing the importance of the usage of the recycled paper in regard to the virgin paper is visible and with it the possible influence on the environment.

The problem statement in the area of ecological sustainability of the sheet fed offset printing comprised in this work is in the domain of the renewable raw materials and the recycled fibers for production of ecologically more suitable graphic materials. These investigations are a part of the project, which includes phases of the printing process through the life cycle assessment, following the important factors of the print quality together with the ecological characteristics. The investigation goal is the contribution to the explanation of deinking process mechanism in relation to the material composition, printing principle and ageing conditions of prints as well as the characteristics of the recycled fibers. The results are applicable in the development of the printing materials new formulation and in the domain of deinking flotation. This is the direction of the continuation of our investigation.

\section{EXPERIMENTAL}

For the print preparation the sheet fed offset printing machine Heidelberg was used. The printing form contained different printing elements: standard CMYK step wedge in the range from $10-100 \%$ tone value, standard ISO illustration for the visual control, textual positive and negative microelements, wedges for determination the grayness and the standard wedge with 378 patches for production of ICC profiles. In printing the two commercial inks were used, one was based on the mineral oil and the other contained the greater share of the renewable raw material. The samples were made on the uncoated paper with the characteristics as presented in the Tab. 1 and Tab.2. 


\begin{tabular}{|c|c|c|c|c|}
\hline $\begin{array}{c}\text { Kind of } \\
\text { paper }\end{array}$ & $\begin{array}{c}\text { Grammage } \\
\mathbf{g} / \mathbf{m}^{\mathbf{2}}\end{array}$ & $\begin{array}{c}\text { Caliper } \\
\mathbf{m m}\end{array}$ & $\begin{array}{c}\text { Brightness } \\
\mathbf{\%}\end{array}$ & $\begin{array}{c}\text { Opacity } \\
\mathbf{\%}\end{array}$ \\
\hline $\begin{array}{c}\text { Uncoated } \\
\text { paper }\end{array}$ & 80 & 0.08 & 103.5 & 92 \\
\hline
\end{tabular}

Tab. 1. Characteristics of the printing substrate

\begin{tabular}{|c|c|c|c|}
\hline Paper & $\mathbf{L}^{*}$ & $\mathbf{a}^{*}$ & $\mathbf{b}^{*}$ \\
\hline Non aged & 94.0 & 0.21 & -0.61 \\
\hline Moist heat aged & 93.0 & 0.09 & -2.99 \\
\hline
\end{tabular}

Tab. 2.L*a*b* values for the printing substrate

The life cycle of the sheet-fed offset printed matter is presented in Fig. 1.

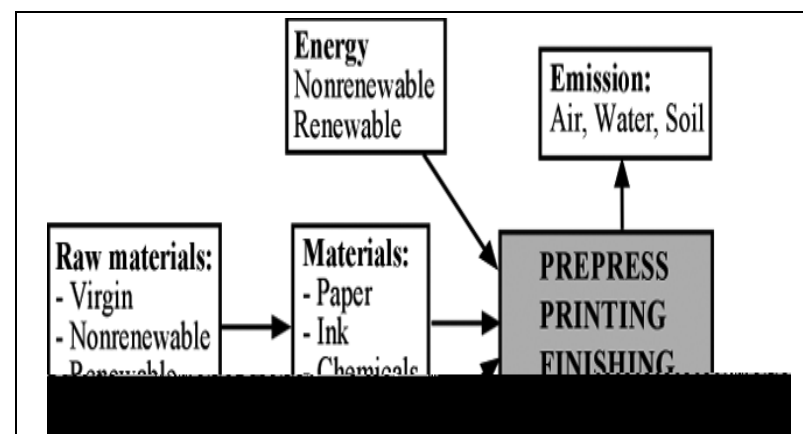

Fig. 1. The life cycle of the sheetfed offset printed matter

According to the INGEDE method $11 \mathrm{p}$ before paper recycling, the samples had to be exposed to accelerated ageing at $60^{\circ} \mathrm{C}$ for 72 hours [30]. According to the same statement these ageing conditions correspond to 3-6 months of natural ageing.

The aim of our project is to find out how the accelerated ageing (the moist heat ageing without light and xenon arc light at determined temperature and relative humidity) in relation to the natural ageing influences on prints on different papers and with different ink compositions, especially those with unsaturated oils, resins or other oxidable component in the ink components.

A part of the answer to the above set question is given by this work. Because of that, before the recycling process, the prints were exposed to the moist heat accelerated ageing with increased temperature and humidity without the influence of the light according to the standard ISO 5630-3 1996, which was used for paper [31]. The samples were moist heat aged for 4,8 and 12 days.

According to Debeljak and Gregor Svetec the 24 daily expositions to the described conditions should be equivalent to 100 years of natural ageing [32].
The prints were recycled by the method of the alkaline chemical deinking flotation, described in details in the quoted work [33]. The handsheets were made using the laboratory sheet former, according to standard method T 205 [34].

For determining ISO brightness of the recycled fibers the spectrophotometer DataColor, Elrepho 450X was used [35].

Specks number and area were assessed with image analysis software Spec*Scan, Apogee System [36]. This system was utilizing the scanner to digitize the image. Threshold value (100), white level (75) and black level (65) were chosen after comparing computer images to handsheet.

\section{RESULTS AND DISCUSSION}

The investigation results of the influence of the sheet fed offset printing technique, paper surface, ink type, ageing of the prints on deinkability are presented in this work.

The brightness of handsheet made from the fibers after the disintegration and after the flotation of prints on uncoated paper with the ink based on mineral oils $\left(S_{1}\right)$ and the one with the increased share of the renewable raw material $\left(\mathrm{S}_{2}\right)$ is presented in Tab 3. In the recycling process the non aged prints were used as well as the moist heat aged ones, aged for 4,8 and 12 days.

\begin{tabular}{|l|l|l|l|l|}
\hline Samples & $\begin{array}{l}\text { Brightness } \\
\text { \% } \\
\text { Non aged }\end{array}$ & $\begin{array}{l}\text { Brightness } \\
\text { Aged 4 } \\
\text { days }\end{array}$ & $\begin{array}{l}\text { Brightness } \\
\text { \% } \\
\text { Aged 8 } \\
\text { days }\end{array}$ & $\begin{array}{l}\text { Brightness } \\
\text { \% } \\
\text { Aged 12 } \\
\text { days }\end{array}$ \\
\hline $\begin{array}{l}\text { S }_{\mathbf{1}} \text { after } \\
\text { disint. }\end{array}$ & 76.06 & 74.05 & 73.62 & 73.13 \\
\hline $\begin{array}{l}\mathbf{S}_{\mathbf{1}} \text { after } \\
\text { flot. }\end{array}$ & 79.21 & 77.89 & 76.01 & 75.99 \\
\hline $\begin{array}{l}\mathbf{S}_{\mathbf{2}} \text { after } \\
\text { disint. }\end{array}$ & 73.42 & 70.94 & 70.70 & 69.61 \\
\hline $\begin{array}{l}\mathbf{S}_{\mathbf{2}} \text { after } \\
\text { flot. }\end{array}$ & 75.05 & 72.23 & 72.01 & 71.27 \\
\hline
\end{tabular}

Tab. 3. Brightness of handsheet made from recycled fibers from aged prints

The results show somewhat greater brightness of handsheet made from the recycled fibers of ink based on mineral oil $(79.21 \%)$ in relation to the ink with greater share of renewable raw material $(75.05 \%)$. Greater difference in handsheet brightness made from recycled fibers of the non aged print with the ink based on mineral oil in relation to the one obtained from the fibers of the non aged print with the ink based on greater share of the renewable raw material is achieved. The difference increased by the print ageing which were used for recycling (brightness on aged prints, ink mineral oil non aged prints, ink renewable raw material $=3.64$, brightness aged prints, ink mineral oil - aged prints, ink renewable raw material $=4.72$.

The effectiveness of deinking can be estimated by image analysis of handsheet made from the recycled fibers. In Tab. 4. the specks number $/ \mathrm{m}^{2}$ and area $\mathrm{mm} / \mathrm{m}^{2}$ of handsheet are presented.

Specks number $/ \mathrm{m}^{2}$ on handsheet made from the recycled fibers of the non aged print with the ink based on mineral oil is for 342889 specks lesser in relation to 



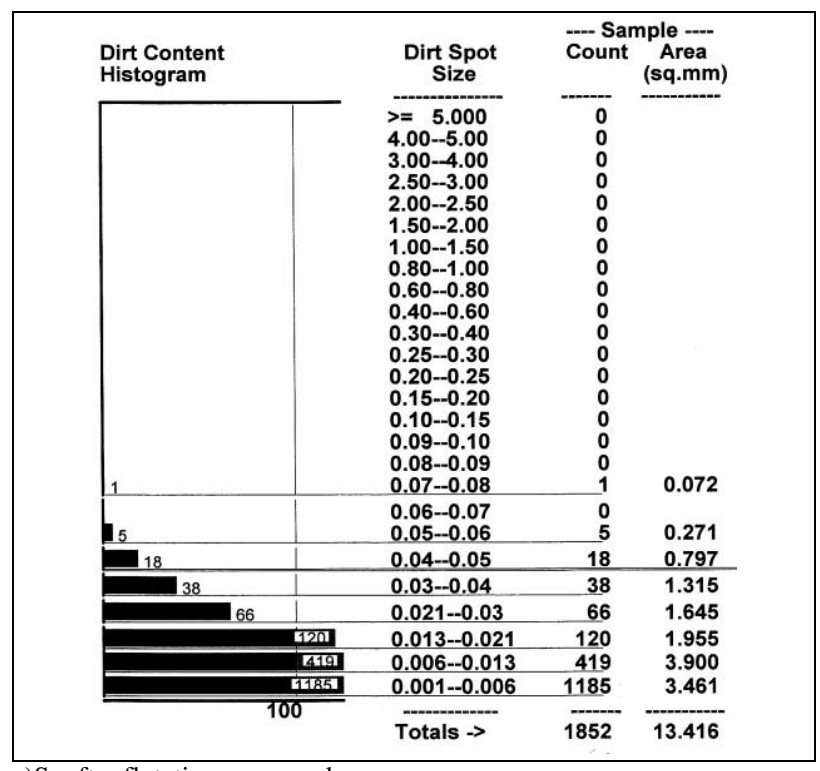

e) $\mathrm{S}_{2}$ after flotation, non aged

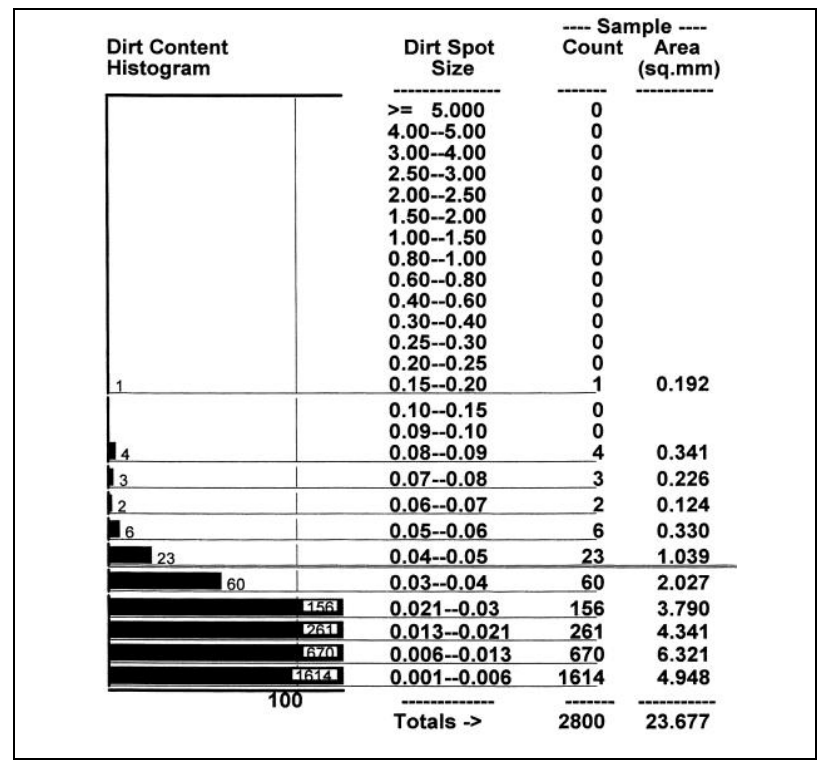

f) $\mathrm{S}_{2}$ after flotation, 4 days moist heat aged

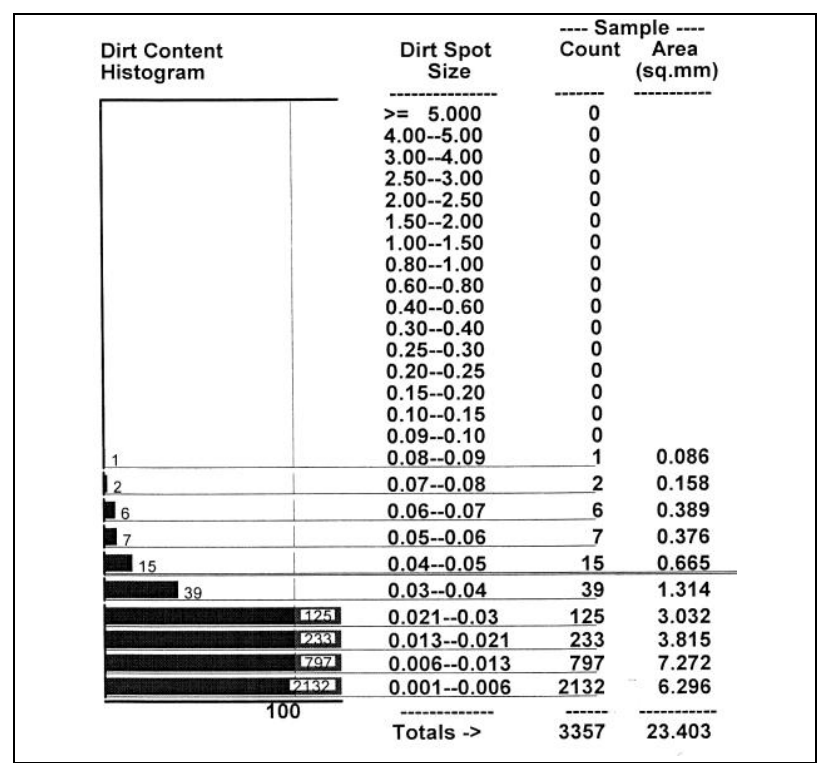

g) $\mathrm{S}_{2}$ after flotation, 8 days moist heat aged

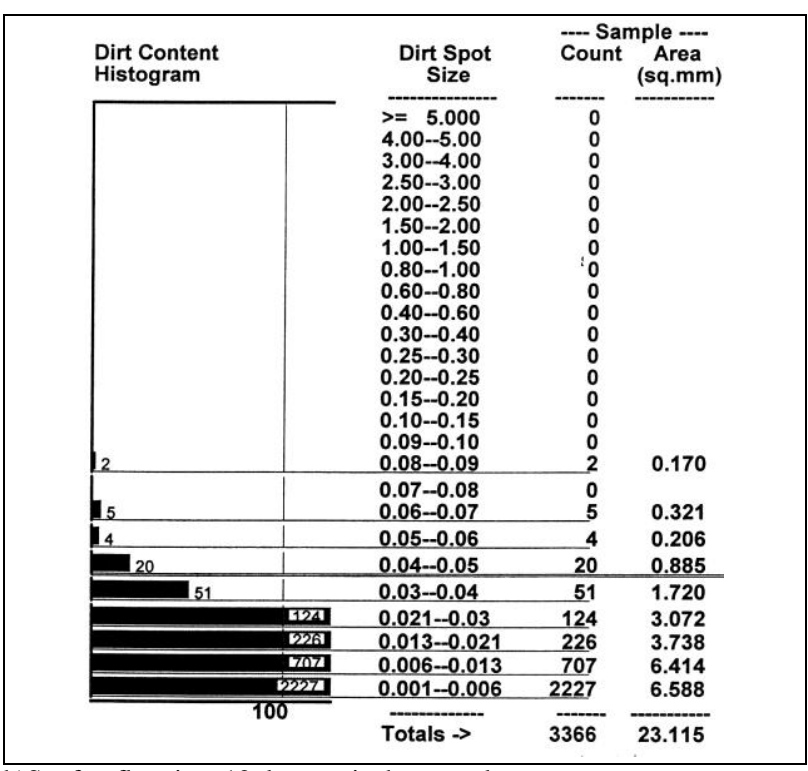

h) $\mathrm{S}_{2}$ after flotation, 12 days moist heat aged

Fig.2. Specks number and area set in size classes for the scanned handsheet surface from $0.003158 \mathrm{~m}^{2}$

Earlier mentioned characteristic of the speck distribution within the size classes is as follows: sample $\mathrm{S}_{1}$, print 12 days aged, size class 0.001-0.006, contain 1280 specks; class $0.006-0.013$ contain 293 specks; class $0.013-0.021$ contain 60 specks. The sample $S_{2}$ in the same conditions and classes contains 2227, 707 and 226 specks . Area of specks on handsheet obtained by processing, on aged $S_{1}$ sample in relation to the aged one for 4 days, for the class $0.001-0.006$,increases for $0.77 \mathrm{~mm}^{2}$ and in relation to 14 days aged print it increases for $2.0 \mathrm{~mm}^{2}$. In the same conditions with the sample $S_{2}$ the area of specks on handsheet will increase for $2.54 \mathrm{~mm}^{2}$, that is 3.08 $\mathrm{mm}^{2}$.

In Tab. 4the chromatic a* (represents color position in red-green area) and $b^{*}$ data (represents color position in yellow-blue area) of handsheets made from the fibres after the disintegration for non aged prints $S_{1}$ and $S_{2}$, and moist heat aged ones are presented. Greater difference of chromatic $\mathrm{a}^{*}$ values of handsheet made from the fibers after disintegration of prints $S_{1}$ in relation to $S_{2}$ can be seen. Handsheets obtained from the fibers of prints with the ink with greater share of the renewable raw material are colored red as it can be seen by the shift of their chromatic value a*. For handsheets obtained by floated fibers with the commercial ink based on mineral oil the shift is made towards the achromatic area. It is characteristic for the sheet fed offset printing that in the formulation of the ink the oxidable components are necessary. The drying mechanism comprises the processes of absorption, evaporation and oxidation.

\begin{tabular}{|l|l|l|l|l|}
\hline Samples & Non aged & $\begin{array}{l}\text { Aged } \\
\text { days }\end{array}$ & $\begin{array}{l}\text { Aged } \\
\text { days }\end{array}$ & $\begin{array}{l}\text { Aged 12 } \\
\text { days }\end{array}$ \\
\hline $\mathbf{S}_{\mathbf{1}} \mathbf{a}^{*}$ & 1.33 & 1.64 & 1.71 & 1.69 \\
\hline $\mathbf{S}_{\mathbf{1}} \mathbf{b}^{*}$ & -3.20 & -3.59 & -4.01 & -4.20 \\
\hline $\mathbf{S}_{\mathbf{2}} \mathbf{a}^{*}$ & 3.21 & 3.98 & 4.02 & 3.99 \\
\hline $\mathbf{S}_{\mathbf{2}} \mathbf{b}^{*}$ & -3.98 & -4.63 & -4.45 & -4.72 \\
\hline
\end{tabular}

Tab. 5. CIE $a^{*}$ and $b^{*}$ values of handsheet made from the fibers after the disintegration of prints $S_{1}$ and $S_{2}$

In the case of print ageing the oxidation process does not stop by print drying. This process further continues and the problem can be in ink detachment and specks. Except that the aged sheet fed offset detachment presents 
difficulties, because the uncoated paper is used in this case and ink print is directly fixed onto the fibers surface.

\section{CONCLUSION}

One of the basic directions of ecological sustainability of sheet fed offset printing is in the area of the application of the renewable and recycling raw material for the production of graphic materials and ecologically justified disposal of the used prints. Based on the investigation results of the influence of sheet fed offset printing technique, paper surface, ink type and moist heat ageing of prints on deniability, the following can be concluded. By ageing of prints, depending on the composition of the printing substrate ink formulation and the drying mechanisms of prints connected with the principles of the printing technique, the oxidation of some ink components appears which then causes the strong attachment of the ink onto fibres.In the process of deinking flotation just the presence of the unsaturated vegetable oils can cause greater ink detachment problems and specks as well as the shift of the chromatic a*value towards the greater values, which causes coloring. The obtained investigation results are the contribution to the knowledge which is applicable for new formulations in the direction of ecological sustainability of the offset sheet fed printing which is the goal of our further investigations.

\section{REFERENCES}

[1] Azapagic, A. (2003). System approach to corporate sustainability. Trans IChemE Part B, Vol., 81., (303-316), ISSN 1088-1980

[2] Spanberger, J.,H., Fuad Luke, A. and Blincoe K. ((2010).Design for Sustainability. Journal of Cleaner Production, Vol.,18., pp. 1485-1493, ISSN 0959-6526

[3] Dalhielm, R.\& Axelsson, U. (1996). MiljöprofileringLivscyhelanalyser av grafiska produkter. Teknik Rapport, 4., (95116), ISSN1652 3237

[4] IFRAS (1998). A life cycle Assesment of the production of a daily newspaper and a weekly magazine. A project of Axel Springer Verlag, Zürich

[5] Ahmadi, A., Williamson, B., H., Theis, T., L. \& Powers, S., E. (2003). Life cycle inventory of toner produced for xerographic processes. Journal of Cleaner Production, Vol., 11., (573-582), ISSN 0959-6526

[6] Azapagic, A(2002). Life cycle assessment: a tool for identification of more sustainable products and processes, In: Handbook of Green Chemistry and Technology, Clark, J. \& Macquarrie, D.,(Eds.), (62-85), Blachwell Science, ISBN 978-0632-05715-3, Oxford

[7] ISO 14040 (2006). Environment management - Life cycle assessment - Principles and framework

[8] ISO 14044 (2006). Environment management - Life cycle assessment -Requirements and guidelines

[9] ISO TR 14047 (2003). Environment management - Life cycle assessment - Examples of application of ISO 14042

[10] ISO TS 14048 (2002). Environment management - Life cycle assessment - Data documentation format

[11] ISO TR 14049 (2000). Environment management - Life cycle assessment - Examples of application of ISO 14041 to goal and scope definition and inventory analysis

[12] .Finnveden, G., Hauschild, M., Z., Ekvall, T., Guinee, J., Heijungs, R., Hellweg, S., Koehler, A., Pennington, D. \& Suh S. (2009). Recent development in Life Cycle Assessment. , Vol., 110, 1-21, Journal of Environmental ManagementISSN 03014797

[13] Larsen, H., F., Hanschild, M. \&HausenM., S.(2006). A life cycle assessment of model sheet fed offset printed matter. A project of University of Denmark,
[14] Nordic Ecolabelling, (2011) Nordic Eco labelling Printing Companies and Printed Matter

[15] Pascal L. \& Schoonenberg C., Comparative life cycle assessment of marketing collateral printing (2010),

[16] Pajola, T., Nors, M. \& Pihkola, H.(2009).Chalenges in carbon footprint calculation and interpretation- Case magazine, IARIGAI Conference, Sweden

[17] Euroth, M.\& Johansson, M. (2006). Environmental data on gravure and offset printing. Acta Graphica, Vol., 18., 4 (1-10), ISSN 03534707

[18] Nors, M., Pajula, T. \& Pihkola, H. (2009) Calculating the carbon footprints of a Finnish newspaper and magazine from cradle to grave. In Life Cycle Assessment of Products and Technologies.Koukkari and Nors (Eds.) LCA Symposium 262, VTT, 6 October 2009, VTT, Espoo.

[19] ReCiPe 2008, A life cycle impact assessment method which comprisesharmonised category indicators at the midpoint and the end point level. Frst edition, Repport 2008

[20] Larsen, H., F., Hanschild, M. \& Hausen M., S. (2008). Ecolabeling of printed matter. In Green Graphic Design, B. Dougherty, Allworth Press. ISBN 13-978-1-58115-511-2 New York

[21] Moberg A., Johansson M., Finnveden G. \& Jonsson A. (2010) Printed and tablet e-paper newpaper from an environmental perspective-A screen life cycle assessment. Environmental Impact Assessment Reviev, Vol. 30, 2010, pp. 177-191

[22] Vercalsteren, A., Dils. E. \& Greerken, T. (2011) Life cycle assessment of printed matter. Flemish Institute for Technological Research, Belgium, 2011

[23] Carre, B., Magnin, L., Gallard G. \& Vernac, Y. (2000) Deinking difficulties related to ink formulations; printing, process and type of paper. Tappi J. Vol. 24, No. 6, 2000, pp. 60-71

[24] Dorris, G., Ben, Y. \& Richard M. (2011) Overview of flotation deinking. Progress in Paper Recycling, Vol.20, No.1, 2011, pp.334

[25] Borchard, J., K. (1995) Ink types: The role of ink in deinking. Progress in Paper Recycling, Vol.5, No.1, 1995, pp.81-87

[26] Renner, K. (2000) Deinkability of printing inks. Recycled Fiber and Deinking. Göttsching L. \& Pakarinen H. (Eds). Fapet Oy. ISBN 952-5216-07-1Jyväskylä

[27] Dorris, G. \& Page N. (2000). Natural and accelerated ageing of old newspapers printed with black mineral oil inks and colored vegetable oil inks. Progress in Paper Recycling, Vol.9, No.4, 2000, pp.14-26

[28] Castro, C., Dorris, G. \& Daneault, C. (2002). Monitoring and caracterization of ink vechicle autoxidation by inverse gas chpomatography. Journal of ChromatographyA. Vol. 9692002 pp.313-322

[29] Haynes, R., D. (2000) The impact of the sommer effect on ink detachment and removal. Tappi J. Vol.83,2002. pp.56-65

[30] INGEDE Method 11p (2009).Assessment of Print Product Recyclability-Deinkability Test, International Association of the Deinking Industry

[31] ISO 5630-3 (1997) Paper and board-Accelerated ageing-Part 3: Moist heat treatment at $80^{\circ} \mathrm{C}$ and $65 \%$ humidity

[32] Debeljak, M. \& Gregor Svetec, D. (2010). Optical and colour stability of aged speciality papers and ultraviolet cured ink jet prints. J. Imaging Sci. Technol. Vol. 54, No. 6, pp. 060402-1

[33] Bolanaca Mirkovic I., Bolanca Z., (2005), Optical properties of deinked pulp.Journal of Imaging Science and Technology, Vol. 49, No. 3, 2005, pp.284-292

[34] .T 205 (2002) Sheet formed from a pulp suspension

[35] ISO2470-1;(2009) paper,board and pulps reflectance factor ISO brightness

[36] T 537:08 (2008) Image analysis dirt count method 